\title{
THE EFFECTS OF INVENTORY MANAGEMENT ON THE PERFORMANCE OF PHARMACEUTICAL SHOPS IN THE BUEA MUNICIPALITY OF CAMEROON
}

\author{
Associate Professor Visemih William Muffee (Ph.D) \\ Higher Institute of Commerce and Management, The University of Bamenda
}

DOI: 10.46609/IJSSER.2021.v06i01.011 URL: https://doi.org/10.46609/IJSSER.2021.v06i01.011

\begin{abstract}
Inventory constitutes majority of current assets of small businesses such as bakeries, fast food/eateries, chain stores, Pharmaceutical shops and furniture making firms. Small businesses need to understand the true costs associated with inventory management and poor inventory productivity so as to be able to review the benefits of alternative approaches. The objective of the study was to examine the effect of inventory management on performance of small businesses in the pharmaceutical sector with the case of Pharmaceutical shops in the Buea municipality in Cameroon. The study used a descriptive research design. The population consists of all Pharmaceutical shops operating in the Buea municipality. The study used a census study. Data for the study were obtained through the administration of a self-designed questionnaire to the pharmacists, workers and accountants of the Pharmaceutical shops. A linear regression analysis was conducted to test each objective established for the study. Findings of the study reveal that inventory Planning, organizinghad a significant positive relationship with financial performance of Pharmaceutical shops while inventory control had no significant effect on the performance of Pharmaceutical shops. The study also reveals that there is a negative relationship between inventory management and customer satisfaction. The study concludes that inventory management has a great role to play in the financial performance of Pharmaceutical shops. Hence firms' inventory systems must maintain anappropriate inventory levels to enhance profitability and reduce the inventory costs associated with holding excessive stock in the warehouses.
\end{abstract}

Keywords: Inventory Management, Inventory Planning, Inventory Recording and On-shelf Arrangement, Inventory control, Performance.

\section{Introduction}

In this global world today, many businesses are facing immense and fierce competition. The management of all activities is of paramount importance. In order to stay alive in the long term, 


\section{International Journal of Social Science and Economic Research}

ISSN: $2455-8834$

Volume:06, Issue:01 "January 2021"

each and every business must endeavor to see that they remain competitive or have a competitive edge over other businesses. The management of Inventory therefore plays an important role in numerous businesses. This means that any ineffective inventory system will result in loss of customers and sales. An effective inventory management is able to generate more sales from the company which directly affects the performance of the company. Therefore, it requires a systematic inventory management which is managed by a group of employees who are experts in this area.

Inventory is very critical to manufacturing and retailing organizations. They may consist of raw materials, work-in-progress, consumables, and finished goods. However, it is not imperative that an organisation has all these inventory classes. Whatever may be the inventory items, efficient management is required, as generally, a substantial share of its funds is invested in them. Different departments within the same organisation adopt different policies towards inventory. This is mainly because the particular functions performed by a department influence the department's choice. For example, the sales department might desire large stock in reserve to meet virtually every demand that comes. The production department similarly would ask for stocks of materials so that the production system runs uninterrupted. On the other hand, the finance department would always argue for a minimum investment in stocks so that the funds could be used elsewhere for other better purposes, (Vohra, 2008:427, as cited in Anichebe \& Agu 2013).

Generally, Inventory management is a function or a process which is of great and vital importance within most businesses, if not all. Many a time companies are capable of maximizing their rate of return and minimizing liquidity and business risk by optimally managing inventory. Inventory management involves comparison between the costs associated with keeping inventory and the benefits of holding inventory. Successful inventory management minimizes inventory spoilage, reduces cost and generally improves profitability. Thus, financial managers have a responsibility both for raising the capital needed to carry inventory and for the firm's overall profitability. The goals of inventory management are to ensure that the inventories needed to sustain operations are available, but to hold the costs of ordering and carrying inventories to the lowest possible level. There is always pressure to reduce inventory as part of firms' overall cost containment strategies, and many firms are taking drastic steps to control inventory costs (Brighamand Daves, 2004)

However, the allocation of resources within an organization has become a pertinent issue. Organizations have to acquire, allocate and control production inputs which are vital for the success of any business venture. Inventory management as one of the essential activities of a business, has always been a content of cognition for the growth and long-term survival of businesses. The main objective of inventory management is making sure excess stocks are not 


\section{International Journal of Social Science and Economic Research}

ISSN: $2455-8834$

Volume:06, Issue:01 "January 2021"

held, thereby having to tie up capital so as to guide against incurring costs such as storage, spoilage, pilferage and obsolescence, also the desire to make goods available when and where required, so as to avert the cost of not meeting such requirements.

Thus, from the classical view point or perspective, inventories of raw materials, work-inprogress components and finished goods were kept as a buffer against the possibility of running out of needed items of stock. However, large buffer inventories consume valuable resources and generate heavy hidden costs. Consequently, many companies have changed their approach to production and inventory management. Since the early 1980 s, inventory management leading to inventory reduction has become the primary target, as is often the case in just-in-time (JIT) systems, where raw materials and parts are purchased or produced just in time to be used at each stage of the production process.

Inventory is classified based on the business undertaking from organisation to organisation. Common criteria used are nature of inventory for example manufacturing, sale or retail, purpose for which inventory is being held in stock or function and the related usage in the supply chain. Typical classifications are raw materials (items in unprocessed state awaiting conversion (e.g. timber, steel and coffee seeds), components and sub-assemblies. These are for incorporation into the end product e.g. side mirrors, glasses for car assembling company and monitors or keyboards for a computer assembling company). Consumable (all supplies in an undertaking which are classified as indirect and which do not form part of saleable product. (Divided into production, maintenance, office and welfare). Proper classification of inventory and its control improve the financial position of a business (Jessop and Morrison 1994).

Inventory management is first and foremost concerned with determining the size and placement of stocked goods. Inventory management is required at different locations within a facility or within multiple locations of a supply network to protect the regular and planned course of production against unexpected disturbances of stock out of materials and goods for improved performance (Garry, 1997). The scope of inventory management also concerns the fine lines between replenishment lead time, carrying costs of inventory, asset management, inventory forecasting, inventory valuation, inventory visibility, future inventory price forecasting, physical inventory, available physical space for inventory, quality management, replenishment, returns and defective goods and demand forecasting (Lau and Snell, 2006).

The incorporation of Information technology (IT) in supply chain management and in particular inventory management holds enormous possibilities to unravelling the effectiveness of inventory management in today's businesses by improving information sharing, increasing predictability, improve monitor of demand for certain products and place orders to prevent stock out thereby reducing lead time ( Fridah, 2015). The availability of information and the techniques or methods 


\section{International Journal of Social Science and Economic Research}

ISSN: $2455-8834$

Volume:06, Issue:01 "January 2021"

of analyzing this information to reach meaningful results is of huge importance in inventory management. Haag and Stephen(2010) advocate that increasing importance of electronic business brings to the frontline new opportunities and the widespread use of internet makes IT tools a source of competitive power for many companies. Furthermore, it has been adopted in inventory management processes by firms as a competitive edge to build strategic long-term relationships.

That notwithstanding, poor inventory management had become an issue of great concern since performance is regarded as the main stream for development of organizations. A truly effective inventory management system minimizes the complexities involved in planning, executing and controlling inventory which is critical to business success. The opportunities available by improving a company's inventory management can significantly improve bottom line business performance.

As such, Jayeff (1998) asserted that from a financial perspective, inventory management is no small matter. Frequently, inventory is the largest asset item on a manufacturer's or wholesaler's or retailer's balance sheet. As a result, there should be a lot of management emphasis on keeping inventories. The aims of inventory reduction and minimization are more easily accomplished with modern inventory management processes, which are working effectively for the improvement of performance. The work of inventory management is much more complex than initially understood. In fact, in the soft drinks industry the inventory control department is perceived as little more than a clerical function as it is probably not very effective. The result of this to inventory management is lots of material shortages, excessive inventories, high costs and poor customer service, (Mohamad 2016).

Too much inventory and not enough customer service is very common and unnecessary. There are techniques that can accurately forecast customer's demand and to calculate the inventory needed to meet defined level of customer service. Using the right techniques for sales forecasting and inventory management help to monitor changes and respond to alerts, when action needs to be taken. The right approach to inventory management can produce dramatic benefits in customer service with lower inventory.

Therefore, with respect to inventory management, Baron et al (2010) advised that effective inventory management practices need to be adapted. Nkiemboupoh, Roland and Abonwi (2017) suggested that inventories are necessary for keeping the production wheels moving, the market going and the distribution system intact. Therefore, it is pretty clear at this juncture that controlling and monitoring inventory is very important and contributes greatly to a firm's profitability. 


\section{International Journal of Social Science and Economic Research}

ISSN: $2455-8834$

Volume:06, Issue:01 "January 2021"

Inventory management in contemporary times make use of new and reliable techniques not excluding the use of sophisticated tools and systems (software) that enable improved performance of inventories to maximize customer service with low inventory and costs. These improved approaches to inventory management are of major consequence to overall competitiveness where the highest level of customer service and delivered value can favorably impact market share and profits. However, on the other side Pharmaceutical shops in Buea municipality uses different kinds of inventory management, what is not brought out is how such kinds affect the performance of the Pharmaceutical shops situated in Buea.

\section{Statement of the Problem}

Many small businesses operate nowadays in a very dynamic, challenging and highly competitive environment with immense pressure from political and economic factors. In order to succeed, businesses must realize that inventory management is an indispensable and critical factor. This is so because the use of poor inventory management systems will result or lead to loss of customers, sales and above all profits. However, an effective inventory management system would result in increased revenue for the business which in turn affects the performance of the business in terms of profitability as well as other indicators. Inventory management plays a vital role in every business since ineffective inventory system willresult in loss of customers, sales and ultimately profits. An effective inventory management will becapable of creatingmore sales for the company which directly affects the performance of the company in terms of profitability andother indicators (Bin, Mohamad, Rahman and Suhaimi, 2016).

Moreover, various signs such as the loss of customers, increased cost, dissatisfaction of customers as a result of poor service to them, delay in delivery time, have been very evident in many Pharmaceutical shops in the Buea municipality for the past decade. With respect to this, Temeng, Eshun and Essey (2010), argued that companies have ignored the possibility of cost savings from proper inventory management viewing inventory as an indispensable aspect of business and not as an asset which requires proper management. As a result, inventory systems decisions have been limited to subjectivity.

Unfortunately, it is not unusual for a business to have money tied up in inventory and still not capable of satisfying customer needs because of ineffective inventory management (Temeng et al., 2010). According to Anichebe \& Agu (2013), Inventory represents an important decision variable at all stages of product manufacturing, distribution and sales, in addition to being a major portion of total current assets of many organizations. It represents $33 \%$ of company assets and as much as $90 \%$ of working capital. Therefore, unless operators in the manufacturing industry understand the true costs associated with inventory management and poor inventory 


\section{International Journal of Social Science and Economic Research}

ISSN: $2455-8834$

Volume:06, Issue:01 "January 2021"

productivity, and evaluate the benefits of different approaches, they will remain complacent, accepting average profit instead of better performance (Prempeh, 2016).

Problems associated with inventory management have been in existence for quite a long time now and managers are fully aware of how vital inventory is to the operations of an organisation. To be more precise, knowing which optimal level of stock that minimizes cost and maximizes revenue is problematic. This is so because having few inventories in store might lead to stock out and eventually incurring of stock out costs, while on the other hand, holding more stock than required will also lead to more carrying costs.Muhamad (2016) asserted that inventory management involves the planning, ordering and scheduling of the materials used inthe manufacturing process. It exercises management over three types of inventories that is rawmaterials, work in progress and finished goods.In his research on the effects of inventory management on the performance of businesses in Modigahsu, Somalia, he brought out the inventory management process as planning inventory, recording inventory, valuing inventory and controlling inventory.

Pharmaceutical shops have to some extent lost their identification as a professional institution offering advice. Although pharmacists are medicine experts they are often seen as the final step in the supply chain and do not utilize their knowledge and training to form an integral part of the supply chain (Harrison et al., 2012). The role of the pharmacist is highlighted by the Pharmaceutical Society of South Africa, which stated in the Health Care 2000 report that a pharmacist's main income should be derived from providing professional services rather than trading in medicine (Bruin, 1990). Over time, however, the lines between professionalism and a firm that is selling goods and trying to make a profit have become blurred. The question has been asked as to whether or not pharmacists are acting as professionals or as shopkeepers (Williams, 2007). In reality, pharmacists often have to carry out a dual role. This role portrays them as health care professionals and business owners (Schmidt and Pioch, 2001). However, there has been a shift in their role over time from providing pharmaceutical care to service-oriented business. One important task of such a business is to manage its front end or retail store better (Patel and Pande, 2012).

Pharmaceutical shops with high level of finished goods inventory have the opportunity to provide variety of products to customers. However, despite the fact that the strategic importance of effective inventory management is known in theory, in Cameroon it is evident that effective inventory management is not adequately practiced. Great amounts of a company's cost can be attributed to the amount of it invests in inventory. The goal of inventory management, therefore, is to have adequate quantities of inventory available to serve customer needs, while also minimizing the costs of carrying inventory thus improving the overall performance. Companies adopt inventory policies based on the various inventory control theories to achieve the perfect 


\section{International Journal of Social Science and Economic Research}

ISSN: $2455-8834$

Volume:06, Issue:01 "January 2021"

equilibrium between inventory costs and inventory availability. The study therefore sought to find outwhether inventory management affects the performance of Pharmaceutical shops in the Buea municipality. The problem as stated brings to mind the following specific research questions:

I. How does planning of inventory affect performance of Pharmaceutical shops in Buea?

II. What effect does inventory recording and arrangement on shelves have on performance of Pharmaceutical shops in Buea municipality?

III. What is the effect of inventory control systems on performance of Pharmaceutical shops in Buea municipality?

\section{Objectives of the Study}

The Main Objective is to assess the effects of Inventory management on performance of Pharmaceutical shops in the Buea municipality. This gives rise to the following specific objectives:

I. To assess how inventory planning affects the performance of Pharmaceutical shops

II. To assess the effect of inventory recordingand on-shelf arrangement of inventory on the performance of Pharmaceutical shops

III. To evaluate the effect of inventory control system on the performance of Pharmaceutical shops

\section{Statement of Hypothesis}

\section{a. Inventory planning and Performance}

i. $\quad \mathbf{H}_{\mathbf{0}}$ : Inventory planning does not significantly affect the performance of Pharmaceutical shops.

ii. $\quad \mathbf{H}_{1}$ : Inventory planning significantly affects the performance of Pharmaceutical shops

\section{b. Inventory recording and on-shelf arrangement and Performance}

i. Ho: Inventory Recording and On-shelf arrangement does not significantlyaffects the performance of Pharmaceutical shops.

ii. H1: Inventory Recording and On-shelf arrangement significantly affects the performance of Pharmaceutical shops.

\section{Inventory Control and Performance}




\section{International Journal of Social Science and Economic Research}

ISSN: $2455-8834$

Volume:06, Issue:01 "January 2021"

I. $\mathbf{H}_{0}$ : Inventory Control Systems do not significantly affect the performance of Pharmaceutical shops.

II. $\quad \mathbf{H}_{1}$ : Inventory Control Systems significantly affects the performance of Pharmaceutical shops

\section{Literature Review}

According to Agu, Happiness and Chukwuma (2016), inventory management incorporates all activities put in place to make sure that the customer has the needed product or service. It coordinates the purchasing, manufacturing and distribution functions to meet the marketing needs and organizational needs of availing the product to the customers. Inventory management is primarily involved with specifying the size and placement of stocked goods. Inventory management is required at different locations within a facility or within multiple locations of a supply network to protect the regular and planned course of production against the random disturbance of running out of materials. The scope of inventory management also involves managing the replenishment lead time, replenishment of goods, returns and defective goods and demand forecasting, carrying costs of inventory, asset management, physical inventory, available physical space, inventory valuation, inventory visibility, future inventory price forecasting and quality management. With a balanced of these requirements, it is possible to reach an optimal inventory level, which is an on-going process as the business needs a shift and react to the a wider environment (Ogbo et al..,2014). Inventory control means availability of materials whenever and wherever required by stocking adequate number and kind of stocks. The sum total of those related activities essential for the procurement, storage, sales, disposal or use of material can be referred to as inventory management. Inventory managers have to stock-up when required and utilize available storage space resourcefully so that available storage space is not exceeded. Maintaining accountability of inventory assets is their responsibility. They have to meet the set budget and decide upon what toorder, how to order and when to order so that stock is available on time and at the optimum cost (Benedict and Margeridis, 1999). Hence, inventory management involves planning to organizing and controlling the flow of materials from their initial purchase unit through internal operations to the service point through distribution (Smaros, et al., 2003).

Controlling inventory for small businesses in developing countries like Cameroon is of critical importance. A firm must employ some good inventory techniques to improve their financial situation. According to Kotler (2002), inventory management is a technique of managing, controlling and developing the inventory levels at different stages. That is, raw materials, semifinished goods and finished goods, so that there is regular supply of resources at minimum costs. Inventory management is concerned with how much to keep on hand, how frequently to reorder, and how much to order. It is essential for day-to-day operations with the objective of meeting customer needs while keeping inventory costs at a reasonable level (Mercado, 2007). Inventory control may range from holding stock and reordering only when customers place an order (Just 


\section{International Journal of Social Science and Economic Research}

ISSN: $2455-8834$

Volume:06, Issue:01 "January 2021"

in Time inventory management) to keeping relative levels of inventory after anticipation of customer needs (Mercado, 2007).

Inventory management refers to all activities involved in developing and managing the inventory levels, whether the inventory is raw materials, semi-finished materials or finished goods, so that adequate supplies must always be available and the form must make sure that the cost of over or under stocks are always low, (Anichebe \&Agu, 2013). According to Mohamad, Suraidi, Rahman and Suhaimi (2016) an effective inventory management is able to generate more sales for the company which directly affects the performance of the company. Basically, inventory management has two goals. First goal is to make available the goods at right place in right time because it is very important to keep operations running to give specific service. Second goal is to achieve the service level against optimal cost (Shardeo, 2015).

It is very difficult to achieve goal against optimal cost. All items cannot be stocked, so there is need to specify the important goods to be stocked. The supplies inventories involve the materials required for the maintenance, repair and operating that do not go to the final product. But it is also considered as the types of inventories. Inventory should be available in proper quantity at all times, neither more nor less than what is required. Inadequate inventory adversely affects smooth running of business, whereas excess of it involves extra costs, thus reducing profits. The primary objective of inventory management is to avoid too much and too little of it so that uninterrupted production and sales with minimum holding costs and better customer's services maybe possible (Panigrahi, 2013)

Thus, inventory management is also defined as it is the science and art of managing the level of stock of group of items which incurred least costs and also reach the objectives set by the top management. So, on the final note the primary objective of inventory management is to improve the customer satisfaction level. For this one has to keep adequate amount of inventory for demand fluctuations and variability. The secondary objective is to increase the production efficiency. Increasing production efficiency means that the production control, maintaining the level of inventory for efficient materials management.

As the pharmaceutical industry has become more liberalized, the pharmacist has had to focus on remaining competitive. In this regard, it has been proposed that inventory management is key to retail financial success. Controlling the inventory of an entity efficiently requires an understanding of the number of products, the size of the store and the operating hours of the entity (Dubelaar et al., 2001). In a competitive industry, such as the retail pharmaceutical industry, if a pharmacy does not have the appropriate stock available customers will simply go to another pharmacy. The owner of the store thus needs to make decisions relating to how much 


\section{International Journal of Social Science and Economic Research}

ISSN: $2455-8834$

Volume:06, Issue:01 "January 2021"

safety stock he should maintain and how much stock to order, as well as the lead time relating to delivery of this stock (Dubelaar et al., 2001) versus the demand for the stock.

\section{Inventory Planning}

Good inventory management, like everything else starts with good planning. But planning is not just the start, it is the very foundation set for effective inventory control and ironicallyinventory planning happens to be an area that many companies fail to prioritise sufficiently. Inventory planning cuts across a number of supply chain components and comprises all decision-making responsibilities associated with the acquisition and deployment of inventory, which can include raw materials, work in progress and finished goods. These responsibilities extend across functions and when properly exercised is made up of supply, demand, distribution, production, purchasing and capacity planning (logistics bureau, 2017).

Furthermore, inventory planning refers to how units of stock are required by an organization in a given period to allow smooth business processes. A good stock plan set in advance will enable planners to set procurement or purchase dates and quantities that are consistent with the plan to avoid disruptions due to inventory shortages (Muhamad, 2016). Garry, J.Z, (2002) asserted that inventory management involves the planning, ordering and scheduling of the materials used in the manufacturing process. It exercises control over three types of inventories i.e. raw materials, work in progress, and finished goods. Purchasing is primary concerned with control over the raw materials inventory, which includes; raw materials or semi-processed materials, fabricated parts and maintenance, repair and operations.

Inventory planning involves the determination of inventory quantities, timing and alignment with production capacity and sales volume, therefore as a result, it is of strategic importance and directly impacts, on the company's cash-flow and profitability (Logistics Bureau, 2017). Good inventory by its nature is all about creating conditions which make it easy to manage inventory. It provides support to a number of business objectives some of which include control of costs, accurate sales and demand forecasting. Despite the fact that inventory planning is not usually a direct and simple task, it is more realistic and achievable today than it has ever been in the past. This is thanks to the technological tools made accessible to companies nowadays. With all these at the disposal of companies, they are expected to be at the top of their planning game, because if not, the ability to manage inventory will diminish, operating costs will be higher than they need to be and revenues will drop.

\section{Inventory Recording}

Precise and up-to-dated stores records are answers to effective stores management. The fundamental procedures include counting and recording promptly after receipt or production and 


\section{International Journal of Social Science and Economic Research}

ISSN: $2455-8834$

Volume:06, Issue:01 "January 2021"

whenever there is a store transaction, issue of stores should be properly authorized and show details such as code number, quantity of the transaction and the voucher reference (Muller, 2003). It is undertaken by organizations to reduce the errors of stock management and to ensure accurate and reliable stock records. It involves spot checks/ surprise checks, stock taking, which is the physical counting and measuring of quantity of each item in stock and recording the results, (Brooks et al 2007). Checking Receipts - Receipts into store are normally checked (or either by weighing, counting or measuring). If this is done properly, it provides a good foundation for all subsequent operation by ensuring, that the quantities are correct in the first instances. It should be a matter of routine for the store house staff to check the quantities and descriptions of all issues made before they are handed over. It is also common practice to expect the recipient to counter-check the quantity received and to sign for it. This provides a reasonable assurance that quantities taken off stores are correct. Spot checking - Spot-checking is the practice of making random checks of some items at irregular and unspecified intervals. It is often done by senior stores officers in course of their supervisory duties, but can also operate in paralleled with the stocktaking programmed, irrespective of whether the periodic or continuous method is in use. Where the main stocktaking is carried out annually on a periodic basis, spot checking throughout the year is the best safe guard against malpractice during the period between stock takings

\section{Inventory Valuation}

Inventory refers to the goods meant for sale or unsold goods. In manufacturing, it includes raw materials, semi-finished and finished goods. Inventory valuation is done at the end of every financial year to calculate the cost of goods sold and the cost of the unsold inventory.

Inventory valuation is the monetary amount associated with the goods in the inventory at the end of an accounting period. The valuation is based on the costs incurred to acquire the inventory and getting it ready for sale. Inventories are the largest current business assets. Inventory valuation allows you to evaluate your Cost of Goods Sold (COGS) and, ultimately, your profitability. The most widely used methods for the costing of inventories are FIFO (first-in, first-out), LIFO (lastin, first-out) and WAC (weighted average cost). It is very necessary to understand that FIFO, LIFO and WAC are not inventory valuation methods. The help to bring out cost figures which can be used for inventory valuation. Hence, they provide the cost figures used for inventory valuation. This means that, for the valuation of inventory to be accurately done, we have to use the principle that states that inventory is valued at the lower of cost and/or net realizable value (NRV) figures. It is important that during the valuation process, inventory items should not be aggregated. Inventory items must be valued separately, i.e. one after the other. It should be carefully noted that inventory valuation affects performance. This means that whenever 
International Journal of Social Science and Economic Research

ISSN: 2455-8834

Volume:06, Issue:01 "January 2021"

inventory is over-valued, profit is over-stated. Table 1 gives an example of how inventory should be valued.

Table 1: Inventory Valuation

\begin{tabular}{|l|l|l|l|l|}
\hline S.N & Description & $\begin{array}{l}\text { Cost Using FIFO, LIFO } \\
\text { and WAC }\end{array}$ & $\begin{array}{l}\text { Net Realisable } \\
\text { Value }\end{array}$ & $\begin{array}{l}\text { Valuation } \\
\text { Amount }\end{array}$ \\
\hline 1 & Tablets of Soap & 50,000 & 65,000 & 50,000 \\
\hline 2 & Pairs of Shoes & 70,000 & 60,000 & 60,000 \\
\hline 3 & Calculators & 45,000 & 35,000 & 35,000 \\
\hline & Total & $\mathbf{1 6 5 , 0 0 0}$ & $\mathbf{1 6 0 , 0 0 0}$ & $\mathbf{1 4 5 , 0 0 0}$ \\
\hline
\end{tabular}

Source: Visemih (2020)

We have three inventory items for valuation with different cost and net realizable value figures. Table 1, shows the following:

I. Item 1, Tablets of soap have a Cost of 50,000 CFAF and a Net Realiable Value of 65,000 CFAF, which means that we value it at 50,000 CFAF being the cost.

II. Item 2, Pairs of Shoes have a Cost of 70,000 CFAF and a Net Realiable Value of 60,000 CFAF, which means that we value it at 60,000 CFAF being the net realizable value.

III. Item 3, Calculators have a Cost of 45,000 CFAF and Net Realiable Value of 35,000 $\mathrm{CFAF}$, which means that we value it at 35,000 CFAF being the cost.

The 3 items have a valuation amount of 145,000 CFAF. However, if the items were aggregated, the inventory items would have been valued at 160,000 CFAF. If the aggregated valuation is adopted, the inventory items would definitely be over-valued. Over-valuation means that the profit of the period would be over-stated, as seen on table 2.

We can use the following example:

Atabong Enterprise has provided us with the following data extracted from its books:

i. Sales of $750,000 \mathrm{CFAF}$

ii. Purchases of 550,000 CFAF

iii. Closing Inventory at over-valuation 160,000 CFAF 
International Journal of Social Science and Economic Research

ISSN: 2455-8834

Volume:06, Issue:01 "January 2021"

iv. Closing Inventory at normal valuation 145,000 CFAF

We can now use the data to prepare profit statements

Table 2: Profit Statements for Normal and Over-valuation

\begin{tabular}{|l|l|l|l|l|l|}
\hline \multicolumn{2}{|l|}{ Inventory at Normal Valuation } & \multicolumn{3}{l|}{ Inventory at Over-Valuation } \\
\hline Sales & & 750,000 & Sales & & 750,000 \\
\hline & & & & 550,000 & \\
\hline Purchases & 550,000 & & Purchases & 160,000 & \\
\hline Less Closing Stock & 145,000 & & Less Closing Stock & & 390,000 \\
\hline Cost of Goods Sold & & 405,000 & Cost of Goods Sold & & \\
\hline & & & & & $\mathbf{3 6 0 , 0 0 0}$ \\
\hline Gross Profit & & $\mathbf{3 4 5 , 0 0 0}$ & Gross Profit & & \\
\hline
\end{tabular}

Source: Visemih (2020)

Table 2, confirms the fact that when inventory is over-valued, the period's profit becomes overstated. This is true, the period's inventory is over-valued at 160,000 CFAF, instead of at 145,000 CFAF and this has caused a difference in profit of 15,000 CFAF $(360,000-345,000)$.

The principles of inventory valuation follow the prudence concept which states that:

i. Do not anticipate profit, but

ii. When a loss is foreseen, write off immediately.

According to Kotler (2000), inventory management refers to all the activities involved in developing and managing the inventory levels of raw materials, semi-finished materials (workin- progress) and finished good so that adequate supplies are available and the costs of over or under stocks are low (Rosenblatt, 2002). Thus, the overall goal of inventory is to have what is needed, and to minimize the number of times one is out of stock. Drury (2004) defined inventory as a stock of goods that is maintained by a business in anticipation of some future demand.

\section{Inventory Levels}

Inventory management is to make decisions concerning the appropriate stock level. There are four main types of stock levels which are:

\section{The Maximum Stock Level}

This is the level of stock attained when the stocked of goods is fully replaced. It is the sumof minimum level and EOQ. The amounts to be fixed as maximum level depend upon the factors like space available, nature of materials. It can be calculated mathematically as: 
Max stock level $=$ Reorder stock level + Reorder quantity $-($ minimum usage $\mathbf{x}$ minimum lead time)

\section{Minimum Stock Level}

This is the lowest level to which stock should fall. The minimum quantity of stock held at this level is called buffer or safety stock and it is held for reasons like prevention of stock out. The minimum level of inventories kept on the different bases like consumption during the lead time, stock-out costs, customer irritation and loss of goodwill etc. To continue production, it is very essential to maintain optimal number of inventories. The stock which takes care of the fluctuation in demand is known as safety stock. It also governs the ordering point. Mathematically, it can be calculated thus:

Min Stock Level $=$ Reorder Stock level $-($ average usage $\mathbf{x}$ average lead time $)$

\section{Danger Level}

In addition to the minimum and maximum levels, some businesses also determine the danger level of stock. At this level of stock, businesses need to take emergency steps to acquire materials or inventories immediately, otherwise the business operations will stop. This level is not an ideal level of stock, because at this level the company needs to make inventory available on urgent basis, which could increase transportation charges and overall inventory costs. It can be determined mathematically as follows:

\section{Danger Level = Average daily usage $\mathrm{x}$ Lead time for the emergency supply}

\section{Re-order Level}

This is the level of stock which stock is allowed to fall to before an order is placed. This level is set between the maximum and minimum levels in such a way that before material ordered for, are received into the store the minimum would not have reached. It's fixation depends upon the maximum delivery period and maximum consumption.

It is calculated as follows:

\section{Reorder stock level = Maximum Usage X Maximum Reorder Period}

See also figure 1. 
International Journal of Social Science and Economic Research

ISSN: 2455-8834

Volume:06, Issue:01 "January 2021"

Fig. 1: Re-order level

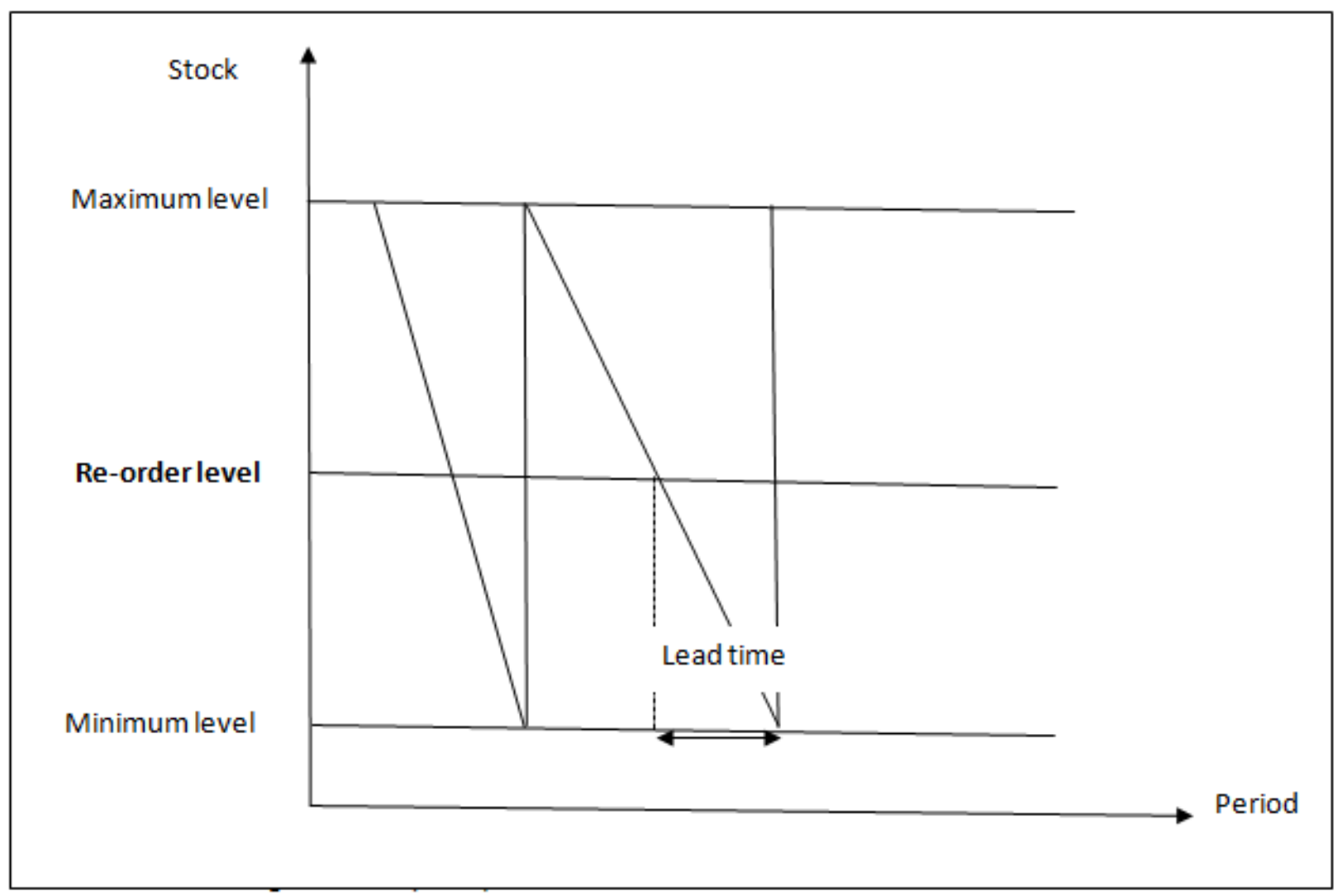

Source: Adopted, Visemih (2020)

The maximum stock level is the level which stocks is not allowed to go above. Minimum stock level refers to the level below which stocks should not normally go down. The Re-Order level is the level at which a company should order more supplies. A fixed re-order level is set for every item of stock. Safety stock is introduced into supply chains to hedge or cater for uncertainty and ensured that customer received the promised service levels, Nkiemboupoh et al., (2017).

It is therefore clear that mismanagement of inventory will lead to tying up excess capital at the expense of profitable operations and suggested that managers can create value for their firms by keeping inventory to an optimum level. This is in line with Sushma \& Phubesh (2007) in their study on Consumer Electronics Industry firms established that businesses' inventory management policies had a role to play in their profitability performance. Likewise, Rajeev (2008) evaluate the relationship between inventory management practices and inventory cost established that effective inventory management practices have a positive impact on the inventory 


\section{International Journal of Social Science and Economic Research}

ISSN: $2455-8834$

Volume:06, Issue:01 "January 2021"

Performance of businesses. In the management of inventory the firm is always faced with the problem of meeting two conflicting needs: maintaining a large size of inventory for efficient and smooth production and sales operations and maintaining a minimum level of inventory so as to maximize profitability (Pandey, 2008). Both excessive and inadequate inventories are not desirable. The dangers of excessive inventories are that stockholding costs are too high and as a result the firm's profitability is reduced. Mohammad (2011) suggests that managers can create value for shareholders by means of decreasing inventory levels.

\section{Inventory Control System}

All firms need to effectively control their inventory and should make sure that any system it adopts to manage its inventory is the most efficient and effective system. Inventory control is the activity which organizes the availability of items to the customers of the organization. It coordinates the purchasing, manufacturing and distribution function to meet the marketing needs. (Mohamud, 2016).

Lyson and Gillingham (2003) suggest that inventory control refers to the techniques used to ensure that stocks of raw materials, work in progress and finished goods are kept at levels which provide maximum service levels at minimum costs. An effective inventory control system should minimize time, carrying costs, maintain sufficient stock for the smooth production, sales operation and efficient customer service. Different business concerns may apply different inventory control practices to meet specific requirements and circumstances to help in containing the costs associated with inventory. .

The perpetual inventory system is a system which continually updates inventory records and accounts for additions and subtractions when inventory items are received and sold from stock. Some businesses prefer this inventory system because they provide up to date inventory information and handles minimal physical inventory count better as well as provide accurate results. The periodic inventory system does not track inventory on a daily basis, rather it permits organizations to know their inventory at the beginning and at the end over a period of time. This type of inventory control system tracks inventory using physical inventory counts. (Indira, Aroon and Prakash, 2018)

The ABC inventory control by Pareto (1970), suggest that all inventory should be classified into three categories as follows: 
International Journal of Social Science and Economic Research

ISSN: 2455-8834

Volume:06, Issue:01 "January 2021"

Table 3: ABC Inventory Classification

\begin{tabular}{|l|l|l|l|l|l|}
\hline S.N & Classification & Value & Cum. \% & Quantity & Cum. \% \\
\hline & & $\boldsymbol{\%}$ & & \% & \\
\hline 1 & A & 80 & 80 & 20 & 20 \\
\hline 2 & B & 15 & 95 & 30 & 50 \\
\hline 3 & C & 5 & 100 & 50 & 100 \\
\hline & & $\mathbf{1 0 0}$ & & $\mathbf{1 0 0}$ & \\
\hline
\end{tabular}

Source: Adopted Visemih (2020)

The Pareto principle was proposed by Vilfredo Pareto in 1887. The ABC analysis is a categorization technique which is based on Pareto's Principle. This principle helps in the determination of what items to be given priority in the management of a firm's inventory (see Table 3).

The $\mathrm{ABC}$ analysis is a basic critical management tool that allows management to put much of their effort where returns will be greatest or highest. The $\mathrm{ABC}$ inventory analysis is beneficial to classify materials based on the demand of the items. It also holds good control over finance, since costly items are under close observation, that is, under category A. Items in-group $\mathrm{B}$ have moderate demand and moderate control. Items in-group $\mathrm{C}$ are very economic and needs not be taken too much care of them (Priyank and Hemant, 2015).

The $\mathrm{ABC}$ analysis of inventories holds that, very small portion of materials contains bulk amount of monetary value, while relatively large portion of material consists less amount of monetary value (Shardeo, 2015). The ABC analysis shares the same ideas as the Pareto's principle which states that $80 \%$ of overall consumption value comes from $20 \%$ of items. Plainly, it means that $20 \%$ of your products will bring in $80 \%$ of your revenues. The ABC analysis works by simplifying it in the following ways:

I. A-items: $20 \%$ of all goods contribute to $70-80 \%$ of annual consumption value of the items

II. B-items: $30 \%$ of all goods contribute to $15-20 \%$ of the annual consumption value of the items

III. C-items: $50 \%$ of all goods contribute only $5 \%$ of the annual consumption value of the items

With this in mind, items or inventory which fall under the A category in any business should be paid close attention and monitored keenly as a loss in a single item will result to the business losing huge sums of money worth the item. This category A- items can then be controlled permanently or perpetually or frequently to avoid loses hence the use of the permanent inventory 
control system. Thus, both the category B and C-items could be given lesser attention since much of the business revenue is not generated from these items. The periodic inventory control system can then be used in this case to monitor the stock under such categories because a loss in any one of the items would not be so costly on the part of the business. Fig. is the graph depicting or explaining the $\mathrm{ABC}$ model;

Fig. 2: ABC Classification

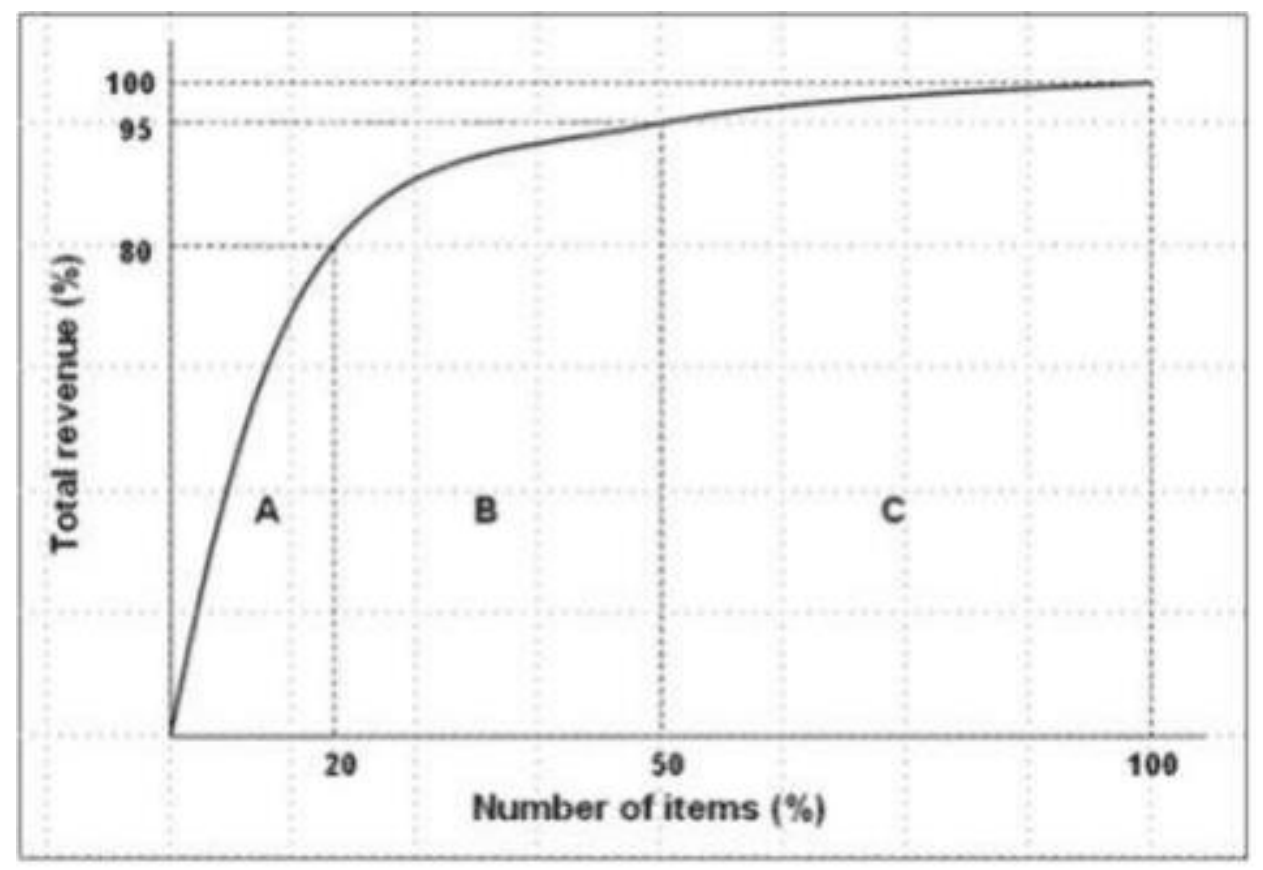

Source: Shardeo (2015

\section{Business Performance}

Performance is a measure of the results achieved. Performance efficiency is the ratio between effort extended and results achieved. The difference between current performance and the theoretical performance limit is the performance improvement zone. Performance assumes an actor of some kind but the actor could be an individual person or a group of people acting in concert. The performance platform is the infrastructure or devices used in the performance act (Malcom, 2005).

Profitability is used in measuring performance of the firm. Profitability is one of major aspects of financial reporting for many firms (Farah and Nina, 2016). Profitability is vital to the firm's manager as well as the owners and other stakeholders that are involved or associated to the firm since profitability gives a clear indication of business performance. Profitability ratios are normally used to measure earnings generated by a firm for a 
International Journal of Social Science and Economic Research

ISSN: 2455-8834

Volume:06, Issue:01 "January 2021"

certain period of time based on the firm's sales level, capital employed, assets and earnings per share. Profitability ratios are also used to measure the firm's earning capacity and considered as a firm's growth and success indicator (Majed, Said \& Firas, 2012). Many firms strive to improve their profitability and they do spend countless hours on meetings trying to come up with away of reducing operating costs as well as on how to increase their sales..

\section{Theoretical Review}

\section{i. The Re-order Quantity and the Theory of Economic Order Quantity}

The re-order quantity is the quantity of items to be ordered so as to continue production without any interruptions in the future. The economic order quantity is just one of the methods in determining the re-ordered quantity among others which include the open access bin system and the two-bin system.

The economic order quantity (EOQ) theory was proposed by Harris (1913) to determine the optimal inventory level. EOQ refers to an inventory quantity that can minimize both inventory holding cost and inventory ordering cost (Lwiki et al., 2013). The EOQ model is used to determine an optimal ordering size that will minimize the sum of ordering and carrying costs (Ziukov, 2015). The EOQ model considers a tradeoff between storage cost and ordering cost when making a decision on the quantity to use when replenishing inventory items. Ordering frequency is usually reduced by a larger amount of quantity ordered, hence ordering cost is reduced, but increases the storage costs and requires a larger space for storage too (Schwarz, 2008). Some costs decline with holding inventory, while others, holding costs increases and the total inventory-associated cost curve has a minimum point (Lwiki et al., 2013). Ordering costs refer to those costs which are incurred when additional inventories are being procured or purchased while carrying costs are the costs incurred for inventory holding. Thus, EOQ is determined by intersection of ordering cost curve and carrying cost line. At this point total carrying cost and total ordering cost are equal to each other (Kumar, 2016). The EOQ method is used in determining an optimal order quantity which will minimize total inventory cost. The EOQ is very useful tool for inventory control and it can be applied to finished goods inventories, work- in- progress inventories and raw material inventories. Itregulates the purchase and storage of inventory in a way to ensure that an even production flow at the same time restricting excess investment on inventories (Kumar, 2016).

\section{ii. Just in Time Model}




\section{International Journal of Social Science and Economic Research}

ISSN: $2455-8834$

Volume:06, Issue:01 "January 2021"

Just in Time (JIT) is a strategy that is meant to improve the financial performance of a business by reduction of excess inventory together with associated cost (Shin, Ennis \& Spurlin, 2015). The JIT model is based on three crucial principles: waste elimination, continuous improvement in product and service quality and involvement of staff/workers in planning and implementation of the firm's strategies (Obiri-Yeboah, Ackah and Makafui, 2015). JIT is a management concept that was invented to specifically help firms in waste avoidance/reduction. JIT encourages waste minimization as well as productivity enhancement. JIT model is able to identify the value chain challenges and helps in reduction of production waste in the system (Kootanaee, Nagendra and Hamidreza, 2013). Just-In-Time (JIT) is about having right items, right quality and right quantity at the right time and place. If JIT is implemented well, it has the potential of enhancing production quality, increase productivity, improve production efficiency and finally reduces wastes and other avoidable costs associated with production (Kootanaee, Nagendra and Hamidreza, 2013). JIT help in reduction of inventory levels within a firm. As such, firms end up lowering their investments in inventories. JIT emphasize on having in hand the minimum required quantity of materials for immediate use. As such, inventory holding costs are substantially reduced (Kootanaee, Nagendra and Hamidreza, 2013).

\section{Empirical Literature}

Several studies have been carried out on inventory management across the world. Anichebe and Agu (2013) conducted research on the effects of inventory management on organizational effectiveness in selected organisations in Enugu State, Nigeria. Descriptive research method, especially survey, and case study were employed in carrying out the study. Data were generated using questionnaire, oral interviews, observations, books, journals and the internet. From the analyses, it was realized that despite the fact that the organisations studied, and portrayed the picture that they were applying the principles of good inventory management, they from time to time ran into adversities of inventory inadequacy. This consequently affected their production, leading to the scarcity of one brand of their products or the other, thereby affecting their profitability and consequential effectiveness negatively. The Findings indicate that there is a significant relationship between good inventory management and organizational effectiveness. Inventory management has a significant effect on organizational productivity. The study concluded that Inventory Management is very vital to the success and growth of organizations.

Kariuki (2013) examined factors that influence effectiveness of the inventory control at the Ministry of State for Provincial Administration and Internal Security in Kenya. The study established that procurement of goods delays, stock-outs and unpredictable change in prices were the effects of the long bureaucratic procurement procedure. The study also found that untimely funds dispatch has a negative effect on inventory control.The study further 


\section{International Journal of Social Science and Economic Research}

ISSN: $2455-8834$

Volume:06, Issue:01 "January 2021"

found that inaccessibility stores records, lack of qualified and well-trained employees hinder an effective inventory management and control system

Timothy, et al.., (2013) examined the impact of inventory management practices on financial performance of sugar manufacturing firms in Kenya. The aim of the study was to investigate the relationship, if any, between inventory management practices and financial performance of sugar manufacturing firms in Kenya. The study adopted a descriptive research design. A survey was conducted on all the eight sugar manufacturing firms in Kenya. Both Primary and secondary data were used. The primary data was collected using structured and semi-structured questionnaires. The secondary data was obtained from the publications of the Kenya sugar Board and from the annual performance statements available in the Year Book of Sugar Statistics. The findings suggested that there was generally more than average positive correlation between inventory management practices and financial performance of sugar companies.

\section{Methodology and Research Design}

Research design constitutes the blue prints for the collection, measurement and analysis of data. The study employed a descriptive survey research design which is recommended by Mugenda and Mugenda (2003) as a good method for fact-finding study. A descriptive survey design aims to accurately and systematically describe a population, situation or phenomenon, and it answers questions of what, when, where and how. This research design was used because it was appropriate to identify characteristics, frequencies, trend, correlations, and categories in a phenomenon. Quantitative methods of descriptive survey research design was applied in the study as well. Quantitative method was important in the research because the study made use of numerical data which was presented in frequencies and graphs. Qualitative methods were used because the researcher made use of related literature, as well as open ended questionnaire, to have in depth understand about the phenomenon under study.

The primary and secondary data will be used. Primary data refers to the data collected from the field for the first time. This will be collected with the help of structured questionnaires, interviews and observations.

Secondary data are those data which have already passed through the statistical process, that is have previously been gathered and can be assessed researchers. Documentary method will be used because it will permit me to get ready-made data and information by passing through various documents such as books, journals and even printed financial statements. The advantage of this method is that it helped me to simplify the task by providing statistical information recorded in terms of numbers and percentages and represented in narrative, tables, charts and graphs. 


\section{International Journal of Social Science and Economic Research}

ISSN: $2455-8834$

Volume:06, Issue:01 "January 2021"

Sample size refers to a number of items to be selected from the universe to constitute a sample. As recommended for research studies by Mugenda \& Mugenda (2003). Sampling is a statistical procedure concerned with the selection of the individual observation which helps us to make statistical inferences about the population. There are 9 registered Pharmaceutical shops in the Buea municipality which include Amazing pharmacy, Salvation pharmacy, Winners pharmacy, Mountain pharmacy, Professional pharmacy, Enamen pharmacy, Compassionate pharmacy, Royal pharmacy and Mount Zion pharmacy. In this light and in this scenario, as a result of the small population size, the researcher resulted in a census study that consisted of about 53 personnel made up of the head pharmacist, cashier, sales person or client service, store keeper. A census study here required the researcher to collect data from the whole population in order for the results gotten to be valid.

In order to fulfill all the objectives of the study, primary data was used. Primary data or raw data is data collected by a researcher from first-hand sources, using methods such as surveys, interviews, or experiments. The primary data used consist responses from questions asked to respondents about the stock management systems and how it affects business performance. Questionnaires where used for the purpose of collecting first-hand data from the respondents. A questionnaire is an instrument used in the survey research used to collect primary data or firsthand information or data from respondents of a study. A questionnaire was used because it was the fast and most cost-effective means for collecting the required data for the study. It also gave the researcher a chance to delimit the responses of the respondents, so as to limit the existence of extraneous variables in the study. Extraneous variables are variables which are present in a study, but is not of interest to the researcher. It distorts the results of the study.

Secondary data is data gathered from studies, surveys or experiments that have been conducted by others or from another research. This study made use of secondary data from various journal and periodic journal, websites, and books for the purpose of building the literature and methodology of the research.

\section{Model Specification}

Business performance (profitability) $=\mathrm{f}$ (Inventory Planning, inventory recording and shelf arrangement, inventory control)

Profitability $=\alpha+\beta 1 \mathrm{IP}+\beta 2 \mathrm{IR}+\beta 3 \mathrm{IC}+\varepsilon$

Where, $\alpha=$ constant term

$\beta 1=$ coefficient of inventory planning

$\beta 2=$ coefficient of inventory recording and arrangement 


$$
\begin{aligned}
& \beta 3=\text { coefficient of inventory control } \\
& \varepsilon=\text { error term }
\end{aligned}
$$

$\mathrm{IP}=$ inventory planning

$\mathrm{IR}=$ inventory recording and on shelf arrangement

$\mathrm{IC}=$ inventory control

\section{Findings of the Study}

\subsection{Inventory Planning}

Table 4: Presence of Inventory Management System

\begin{tabular}{|l|l|l|l|l|l|}
\hline \multicolumn{2}{|c|}{} & Frequency & Percent & Valid Percent & Cumulative Percent \\
\hline \multirow{3}{*}{ Valid } & yes & 48 & 92.3 & 92.3 & 92.3 \\
\cline { 2 - 6 } & no & 4 & 7.7 & 7.7 & 100.0 \\
\cline { 2 - 6 } & Total & 52 & 100.0 & 100.0 & \\
\hline
\end{tabular}

Source: Field Survey Data, 2019

The study attempted to capture the number of institutions which have inventory management systems in place. However, even though the responses gathered have come from all employees of the target Pharmaceutical shops, we find that $92.3 \%$ of the respondents accept that there is an inventory management system in their pharmacy while $7.7 \%$ deny this assertion. This implies that inventory management is a widely used business management tool employed within Pharmaceutical shops in the Buea municipality.

Table 5: Decision Making Assisting Technique

\begin{tabular}{|l|l|l|l|l|l|}
\hline \multicolumn{2}{|l|}{} & Frequency & Percent & Valid Percent & $\begin{array}{l}\text { Cumulative } \\
\text { Percent }\end{array}$ \\
\hline Valid & $\begin{array}{l}\text { quantitative backup } \\
\text { methods (EOQ, LP etc.) }\end{array}$ & 12 & 23.1 & 23.1 & 23.1 \\
\cline { 2 - 6 } & \begin{tabular}{l} 
management judgement \\
\cline { 2 - 6 }
\end{tabular} & 24 & 46.2 & 46.2 & 69.2 \\
\cline { 2 - 6 } & 16 & 30.8 & 30.8 & 100.0 \\
\hline
\end{tabular}

Source: Field Survey Data, 2019 
International Journal of Social Science and Economic Research

ISSN: 2455-8834

Volume:06, Issue:01 "January 2021"

Another issue for investigation in the study was the method of assistive decision making used by the Pharmaceutical shops. 23.1\% employed the use of quantitative back-up techniques such as the economic order quantity and the linear programming etc. $46.2 \%$ relied on management judgment, while $30.8 \%$ used the Just in time technique.

Table 6: Descriptive Statistics Results

\begin{tabular}{|c|c|c|c|c|c|c|c|}
\hline \multicolumn{8}{|l|}{ Descriptive Statistics } \\
\hline & $\mathrm{N}$ & Mean & $\begin{array}{l}\text { Std. } \\
\text { Deviation }\end{array}$ & \multicolumn{2}{|c|}{ Skewness } & \multicolumn{2}{|l|}{ Kurtosis } \\
\hline & Statistic & Statistic & Statistic & Statistic & Std. Error & Statistic & Std. Error \\
\hline $\begin{array}{l}\text { Presence of inventory } \\
\text { management system }\end{array}$ & 52 & 1.0769 & .26907 & 3.271 & .330 & 9.043 & .650 \\
\hline Presence of measures & 52 & 1.0962 & 29768 & 2.822 & .330 & 6.200 & .650 \\
\hline $\begin{array}{l}\text { decision making } \\
\text { assisting technique }\end{array}$ & 52 & 2.3846 & 1.15731 & .450 & .330 & -1.297 & .650 \\
\hline Valid N (listwise) & 52 & & & & & & \\
\hline
\end{tabular}

Source: Field Survey Data, 2019

The above inventory planning variables reveal a mean of $1.0769(\mathrm{SD}=0.26907)$ for presence of inventory management system, we find that there is a central tendency around the yes response coded with value $=1$ with a small deviation of responses away from this mean as shown by the standard deviation (SD), it also reveals a kurtosis of 8.8 and skewness of 3.271 implies the data for this variable is positively skewed and not normally distributed. Presence of measures have a mean of 1.0962 ( $\mathrm{SD}=0.29768$ ), skewness of 2.822, and kurtosis of 6.200 , while decision making assisting technique reveals a mean of $2.3846(\mathrm{SD}=1.15731)$, with a kurtosis of -1.297 .

\section{Inventory Recording and on shelf arrangement}

Table 7: Presence of Storage and Transacting System

\begin{tabular}{|c|c|c|c|c|c|}
\hline & & Frequency & Percent & Valid Percent & $\begin{array}{l}\text { Cumulative } \\
\text { Percent }\end{array}$ \\
\hline Valid & Yes & 52 & 100.0 & 100.0 & 100.0 \\
\hline
\end{tabular}

Field Survey Data, 2019

In studying the organization of inventory, the researcher investigated the method of storing and transacting of inventory by the Pharmaceutical shops. We realize that all the participants have storage and transacting systems in place for their organizations. 
International Journal of Social Science and Economic Research

ISSN: 2455-8834

Volume:06, Issue:01 "January 2021"

Table 8: Presence of Item Codes for Stock Items

\begin{tabular}{|l|l|l|l|l|l|}
\hline \multicolumn{2}{|c|}{} & & & & Fumulative \\
Frequency & Percent & Valid Percent & Percent \\
\hline Valid & Yes & 25 & 48.1 & 48.1 & 48.1 \\
\cline { 2 - 6 } & No & 27 & 51.9 & 51.9 & 100.0 \\
\cline { 2 - 6 } & Total & 52 & 100.0 & 100.0 & \\
\hline
\end{tabular}

Source: Field Survey Data, 2019

Also, item codes are more often used a means of tracking, identifying and organ sing inventory items. As shown on table 4.10, $48.1 \%$ of the respondents use item codes for their stock organization while $51.9 \%$ do not.

Table 9: System of Stock Arrangement on Shelves and Counters

\begin{tabular}{|c|c|c|c|c|}
\hline system of $\mathbf{s t}$ & k arrangen & nent on $\mathrm{s}$ & elves and coun & aters \\
\hline & Frequency & Percent & Valid Percent & $\begin{array}{l}\text { Cumulative } \\
\text { Percent }\end{array}$ \\
\hline \begin{tabular}{|l|l} 
Valid & Yes
\end{tabular} & 52 & 100.0 & 100.0 & 100.0 \\
\hline
\end{tabular}

Source: Field Survey Data, 2019

The arrangement of inventory on shelves provides for easy access of stock items by pharmacy attendants, beautifies the shop and attracts customers. As such, the researcher investigated the employment of inventory arrangement techniques by these Pharmaceutical shops. As shown, all participants of the study.

Table 10: Descriptive Statistics for Inventory Recording and On-shelf Arrangement

\begin{tabular}{|l|l|l|l|l|l|}
\hline & $\mathrm{N}$ & Minimum & Maximum & Mean & Std. Deviation \\
\hline $\begin{array}{l}\text { Presence of storage and } \\
\text { transacting system }\end{array}$ & 52 & 1.00 & 2.00 & 1.1346 & .34464 \\
\hline $\begin{array}{l}\text { presence of item codes for } \\
\text { stock items }\end{array}$ & 52 & 1.00 & 2.00 & 1.5192 & .50450 \\
\hline
\end{tabular}


International Journal of Social Science and Economic Research

ISSN: 2455-8834

Volume:06, Issue:01 "January 2021"

\begin{tabular}{|l|l|l|l|l|l|}
\hline $\begin{array}{l}\text { system of stock arrangement } \\
\text { on shelves and counters }\end{array}$ & 52 & 1.00 & 1.00 & 1.0000 & .00000 \\
\hline Valid N (listwise) & 52 & & & & \\
\hline
\end{tabular}

Source: Field Survey Data, 2019

The descriptive statistics for inventory organization reveals that for storage and transacting system and the system of shelf arrangement, a mean of 1 is obtained with $\mathrm{SD}=0.000$, with 0 skewness and kurtosis values. Item codes have a mean of $1.5192(\mathrm{SD}=0.50450)$, presence of storage and transacting system reported a mean of.1346 (SD = 0.34464). The purpose of presenting these descriptive statistics is to present the degree of consensus on the practice of inventory recording and on-shelf arrangement as well present the degree of deviation by some respondents away from this consensus as measured by the Standard Deviation.

\section{Inventory Control and Systems Used}

Inventory control is designed depending on the value of the inventory. Class A inventory applies the perpetual inventory system, while class B applies the short periodic inventory system and class $\mathrm{C}$ applies the long periodic inventory system.

Table 11: Inventory Control and Systems Used

\begin{tabular}{|l|l|l|l|l|l|}
\hline \multicolumn{2}{|l|}{} & & & & \multicolumn{2}{|c|}{$\begin{array}{l}\text { Cumulative } \\
\text { Frequency }\end{array}$} & Percent & Valid Percent & Percent \\
\hline Valid & Perpetual Inventory system & 11 & 21.2 & 21.2 & 21.2 \\
\cline { 2 - 6 } & Short Periodic Inventory system & 19 & 36.5 & 36.5 & 57.7 \\
\cline { 2 - 6 } & Long Periodic Inventory system & 22 & 42.3 & 42.3 & 100.0 \\
\hline
\end{tabular}

Source: Field Survey Data, 2019

Inventory control is used to ensure that stock movements and transactions regarding stock are done without pilferage, carelessness and misappropriation. As such, the researcher investigated the various methods employed by the participants in ensuring control for stock. As shown, 
International Journal of Social Science and Economic Research

ISSN: 2455-8834

Volume:06, Issue:01 "January 2021"

$21.2 \%$ of the respondents used perpetual inventory, $36.5 \%$ employed periodic inventory and $42.3 \%$ used the manual inventory control system.

Table 12: Descriptive Statistics for Inventory Control System Used

\begin{tabular}{|l|l|l|l|l|l|}
\hline & $\mathrm{N}$ & Minimum & Maximum & Mean & Std. Deviation \\
\hline system of stock control & 52 & 1.00 & 2.00 & 1.7885 & .41238 \\
\hline Valid N (listwise) & 52 & & & & \\
\hline
\end{tabular}

Source: Field Survey Data, 2019

Stock control shows a mean of $1.7885(\mathrm{SD}=0.41238)$ centering around perpetual and periodic inventory, however we find that there is a high degree of deviation away from this practice as shown by the standard deviation.

18. Regression Results

Table 13: Dependent and Independent Variables

\begin{tabular}{|l|l|l|}
\hline & & \\
\hline Independent variable & Inventory Planning (IP) & $\begin{array}{l}\text { Inventory planning in this } \\
\text { study is measured by use of } \\
\text { decision assisting techniques } \\
\text { of determining optimum } \\
\text { inventory level to maintain } \\
\text { presented on table 4.7 above }\end{array}$ \\
\hline Independent variable & $\begin{array}{l}\text { Inventory recording and on- } \\
\text { shelf arrangement }\end{array}$ & $\begin{array}{l}\text { This variable was measured by } \\
\text { the use storage and transacting } \\
\text { system, on-shelf arrangement } \\
\text { system and item code } \\
\text { assignment presented on } \\
\text { tables 4.9, 4.10 and 4.11 }\end{array}$ \\
\hline Independent variable & Inventory control (IC) & \begin{tabular}{l} 
This variable was measured by \\
\hline \hline
\end{tabular} \\
\hline \hline
\end{tabular}


International Journal of Social Science and Economic Research

ISSN: 2455-8834

Volume:06, Issue:01 "January 2021"

\begin{tabular}{|l|l|l|}
\hline & & $\begin{array}{l}\text { the use of inventory control } \\
\text { systems presented on table } \\
4.12\end{array}$ \\
\hline Dependent variable & Profitability & $\begin{array}{l}\text { Profitability variable was a } \\
\text { scaled variable obtained from } \\
\text { the variables presented on the } \\
\text { reliability test below on table } \\
4.14\end{array}$ \\
\hline
\end{tabular}

Source: Field Survey Data, 2019

Table 14: Item-Total Statistics for Profitability

\begin{tabular}{|l|l|l|l|l|}
\hline & $\begin{array}{l}\text { Scale Mean if } \\
\text { Item Deleted }\end{array}$ & $\begin{array}{l}\text { Scale Variance } \\
\text { if Item Deleted }\end{array}$ & $\begin{array}{l}\text { Corrected Item- } \\
\text { Total } \\
\text { Correlation }\end{array}$ & $\begin{array}{l}\text { Cronbach's } \\
\text { Alpha if Item } \\
\text { Deleted }\end{array}$ \\
\hline $\begin{array}{l}\text { current system minimizes } \\
\text { cost }\end{array}$ & 18.0577 & 11.153 & .671 & .735 \\
\hline $\begin{array}{l}\text { Current IMS has increased } \\
\text { pharmacy profitability }\end{array}$ & 18.3077 & 13.864 & .207 & .834 \\
\hline $\begin{array}{l}\text { Inventory system helps } \\
\text { generate more sales }\end{array}$ & 18.3269 & 11.832 & .589 & .755 \\
\hline $\begin{array}{l}\text { IMS helps to reduce } \\
\text { carrying cost, holding cost } \\
\text { and ordering cost }\end{array}$ & 18.5769 & 12.092 & .498 & .774 \\
\hline $\begin{array}{l}\text { IMS provides best service at } \\
\text { low cost }\end{array}$ & 18.1346 & 10.785 & .710 & .724 \\
\hline
\end{tabular}


International Journal of Social Science and Economic Research

ISSN: 2455-8834

Volume:06, Issue:01 "January 2021"

\begin{tabular}{|l|l|l|l|l|}
\hline $\begin{array}{l}\text { Current system improves } \\
\text { sales }\end{array}$ & 18.4038 & 10.010 & .657 & .736 \\
\hline
\end{tabular}

Source: SPSS Output, 2019

Table 14 shows the list of variables retained in the study used for further analysis of the results presented in the study scaled to constitute the performance variable. The item Cronbach's Alpha statistic if item deleted column shows the reliability of the data if an item is excluded from the study. We however retain all six (6) variables as they report together a sufficiently acceptable level of reliability of 0.795 .

\section{Diagnostic Tests}

Table 15: Pairwise Correlation Matrix

\begin{tabular}{|c|c|c|c|c|}
\hline & & $\begin{array}{l}\text { Inventory } \\
\text { Recording and } \\
\text { on-shelf } \\
\text { arrangement }\end{array}$ & $\begin{array}{l}\text { system of } \\
\text { stock control }\end{array}$ & $\begin{array}{l}\text { Inventory } \\
\text { planning }\end{array}$ \\
\hline \multirow{3}{*}{$\begin{array}{l}\text { Inventory Recording and } \\
\text { on-shelf arrangement } \\
\text { (IR) }\end{array}$} & Pearson Correlation & 1 & .204 & $-.476^{* *}$ \\
\hline & Sig. (2-tailed) & & .146 & .000 \\
\hline & $\mathrm{N}$ & 52 & 52 & 52 \\
\hline \multirow{3}{*}{$\begin{array}{l}\text { system of stock control } \\
\text { (IC) }\end{array}$} & Pearson Correlation & .204 & 1 & -.196 \\
\hline & Sig. (2-tailed) & .146 & & .164 \\
\hline & $\mathrm{N}$ & 52 & 52 & 52 \\
\hline \multirow[t]{3}{*}{ Inventory planning (IP) } & Pearson Correlation & $-.476^{* *}$ & -.196 & 1 \\
\hline & Sig. (2-tailed) & .000 & .164 & \\
\hline & $\mathrm{N}$ & 52 & 52 & 52 \\
\hline
\end{tabular}

Source: SPSS Output, 2019

Table 15 shows that inventory recording and on-shelf arrangement has a positive linear relationship of 0.204 with inventory control measured by the system of stock control and a negative linear relationship of -0.476 with inventor planning. Inventory control on the other hand 


\section{International Journal of Social Science and Economic Research}

ISSN: 2455-8834

Volume:06, Issue:01 "January 2021"

as a weak negative linear relationship with inventory planning of -0.196 . The above table presents a pairwise correlation matrix between the independent variables (inventory planning, inventory recording and inventory control). As shown on the table, there exists no high correlation coefficient between the variables. This would have violated the assumption of no multi-collinearity and made regression results unreliable if there existed significantly high correlations between the variables.

Table 16: Summary Statistics

\begin{tabular}{|l|l|l|l|l|l|}
\hline Model & R & R Square & Adjusted R Square & Estimate & Durbin-Watson \\
\hline 1 & $.727^{\mathrm{a}}$ & .528 & .498 & .53737 & 2.867 \\
\hline
\end{tabular}

a. Predictors: (Constant), inventory planning (IP), system of stock control (IC), Inventory recording and on-shelf arrangement (IR)

b. Dependent Variable: Profitability

Source: SPSS Output, 2019

The regression model summary above provides the $\mathrm{R}$ and $\mathrm{R}$ squared values. The $\mathrm{R}$ value represents the simple correlation which is 0.552 (in the $\mathrm{R}$ column), which indicates a fairly positive degree of correlation. The $\mathrm{R}$ square value indicates how much of the total in the dependent variable, (firm's profitability), can be explained by the independent variable, (inventory planning, inventory recording and arrangement, inventory control). In this case, $30.5 \%$ can be explained.

Table 17: Regression Coefficients

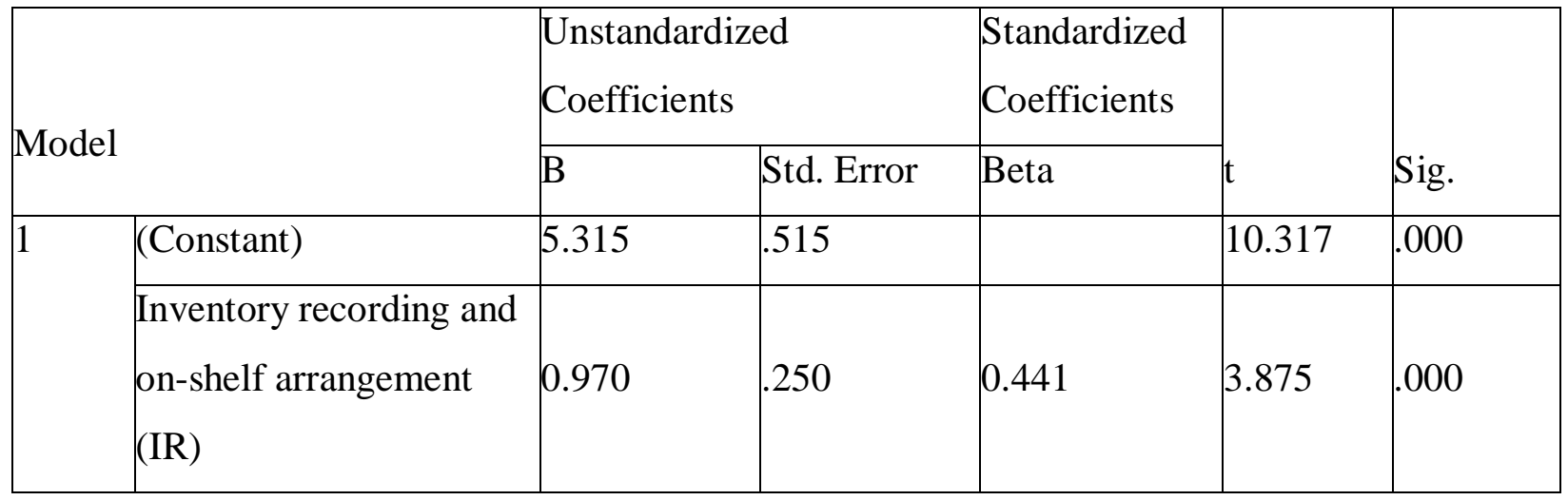


International Journal of Social Science and Economic Research

ISSN: 2455-8834

Volume:06, Issue:01 "January 2021"

\begin{tabular}{|l|l|l|l|l|l|l|}
\hline $\begin{array}{l}\text { system of stock control } \\
\text { (IC) }\end{array}$ & 0.458 & .188 & 0.249 & 2.443 & .018 \\
\cline { 2 - 7 } & Inventory Planning (IP) & .186 & .074 & 0.283 & 2.493 & .016 \\
\hline a. Dependent Variable: Profitability
\end{tabular}

Source: SPSS Output, 2019

Table 17 shows that the coefficients provide us with the necessary information to predict pharmacy profitability from inventory planning, inventory recording and arrangement and inventory control as well as to determine if this prediction is statistically significant to the model by looking at the values of the Sign column. The values in the B column under the unstandardized coefficients column.

The study identifies inventory planning as the putting in place and application of quantitative planning tools for inventory such as the linear programming, economic order quantity, just in time and the $\mathrm{ABC}$ method a well as the mere use of management judgment. As shown, the variable of decision assisting technique used for planning has a coefficient of 0.186 with a pvalue of 0.00 , which is statistically significant at the 0.05 level of significance. In which case, inventory planning has a statistically significant effect on the organizational performance of Pharmaceutical shops in the Buea municipality.

Inventory recording and arrangement accounts for 0.971 of Pharmaceutical shops profitability at a $\mathrm{p}$ value of 0.000 . this implies therefore that inventory recording and arrangement has a statistically significant effect on profitability of pharmacy businesses in the Buea municipality.

Inventory control on the other hand, reports a 0.458 coefficient for determining a firm's profitability. With a p value of 0.018 which is less than the 0.05 level of significance, inventory control has a statistically significant effect on the organizational performance of Pharmaceutical shops in Buea municipality. As such inventory control has a statistically significant effect on the organizational performance of Pharmaceutical shops in the Buea municipality.

In which case an estimation model for profitability using the variables of inventory management can be established as shown below:

Profitability $=5.315+0.0186 \mathrm{IP}+0.971 \mathrm{IR}+0.458 \mathrm{IC}$

\section{Discussion of Results}

The aim of this study is to examine the effect of inventory management on performance of small businesses in the pharmaceutical sector with case study the Pharmaceutical shops in the Buea 
municipality. In discussing the results, the ordinary least squares regression estimates are utilized to examine the relationship between inventory management and performance of 9 Pharmaceutical shops in the Buea municipality. This study utilizes several measures as proxies for inventory management. Findings of the study are discussed below

\section{$\mathrm{H}_{0}$ : Inventory planning does not significantly affect the performance of Pharmaceutical shops}

\section{$H_{1}$ : Inventory planning significantly affects the performance of Pharmaceutical shops}

The regression results indicated that inventory planning has a statistically positive significant effect on the profitability of Pharmaceutical shops in Buea municipality. This is seen with a pvalue of 0.016 which is less than the significance level of 0.05 , therefore we accept the alternative hypothesis and reject the null. This implies that the planning of inventory levels aided with the availability of inventory planning tools will lead to an increase in profits in the Pharmaceutical shops in Buea. These results are in line with the results of Mohamud (2016) who carried out studies on the effect if inventory management on the performance of electronic companies. He ended up with results asserting that inventory planning significantly affects the profitability of companies in Mogadishu positively. These results are in agreement with the findings of Kwame (2007) which established that majority of businesses review their inventory levels and prepare inventory budgets. These findings had already been stressed by Lazaridis and Tryponidis (2006) that enhancing the management of inventory enables businesses to avoid tying up excess capital in idle stock at the expense of profitable ventures. Nyabwanga et al. (2012) assert that good performance is positively related to efficiency inventory management.

\section{$\mathrm{H}_{0}$ : Inventory Recording and On-shelf arrangement does not significantly affect the performance of Pharmaceutical shops.}

\section{$\mathrm{H}_{1}$ : Inventory Recording and On-shelf arrangement significantly affects the performance of Pharmaceutical shops}

The study aimed to see if Inventory Recording and On-shelf arrangement affects the profitability of Pharmaceutical shops in the Buea municipality. The findings of this study indicated that Inventory Recording and On-shelf arrangement had a p-value of 0.000 statistically significant at 0.5 level of significance which meant we accept the alternative hypothesis and reject the null hypothesis. This therefore implied that recording of inventory items when they are acquired and brought in to the store and properly arranging these inventory items on shelves will positively affects the profitability of the Pharmaceutical shops in the Buea Municipality. This result matches the results of Mohamud (2016) in his attempt to show how inventory recording and 
International Journal of Social Science and Economic Research

ISSN: 2455-8834

Volume:06, Issue:01 "January 2021"

arrangement on shelf affects the financial performance of companies in Mogadishu despite using different methods of analysis.

\section{$\mathrm{H}_{0}$ : Inventory Control Systems does not significantly affect the performance of Pharmaceutical shops.}

\section{$\mathrm{H}_{1}$ : Inventory Control Systems significantly affects the performance of Pharmaceutical shops}

Inventory control which is the last but not the least in the inventory management process was tested to determine if it affected the profitability of Pharmaceutical shops in the Buea municipality. The results gotten from the regression showed that inventory control systems were statistically significant, with a P-value of 0.018 lower than the 0.5 level of significance. This implied we reject the null hypothesis and accept the alternative hypothesis. Thus, inventory control captured by the inventory control techniques such as the periodic and perpetual inventory control systems does have a significant effect on the profitability of the Pharmaceutical shops in Buea. This result falls in line with the results of Mohamud (2016) who carried out a study on the effect of inventory control on the performance of companies in Mogadishu. This results also further supports Ogbo, Onekanma and Wilfred (2014) who carried out a study on the effect of the effective system of inventory management on organization performance in the seven-up bottling company Enugu, and resulted that organizations benefit from inventory control management by way of increased sales thus increased profitability.

\section{Summary of Findings}

The study was aimed at determining the effect of Inventory management on the performance of small businesses in the pharmaceutical sector with the case of Pharmaceutical shops in the Buea municipality. The research took place within the Buea municipality examining the whole population to get results. The descriptive survey research design was used and a Likert scaled questionnaire was administered. The study identifies the inventory planning as the putting in place and application of quantitative planning tools for inventory such as the linear programming, economic order quantity, just in time and the $\mathrm{ABC}$ method a well as the mere use of management judgment. As seen, the variable of decision assisting technique used for planning has a coefficient of 0.186 with a p-value of 0.016 , which is statistically significant at the 0.05 level of significance.

As regards Inventory recording and on shelf arrangement, the variable accounted for part of the constant coefficient of 0.970 with a p-value of 0.000 which is statistically significant at the 0.05 level of significance. These results give the researcher the premise to accept the alternative hypothesis which states that inventory recording has a statistically significant effect on the 


\section{International Journal of Social Science and Economic Research}

ISSN: $2455-8834$

Volume:06, Issue:01 "January 2021"

organizational performance of Pharmaceutical shops in the Buea municipality. However, the shelf arrangement variable became a constant in the research with all participants strongly agreeing to establishing shelf arrangements techniques and as such was excluded from the model.

The regression provides us with the necessary information to predict pharmacy profitability from inventory control. As shown, the variable has a coefficient of 0.458 with a p-value of 0.018 , which is statistically not significant at the 0.05 level of significance. These results give the researcher the ground not to reject the null hypothesis which states that inventory control in the form of periodic and permanent inventory control or inventory count does not have a statistically significant effect on the organizational profitability of Pharmaceutical shops in the Buea municipality.

\section{Conclusion}

Inventory management models are essential tools to put inventory at minimum. The organization should not have too much or too little on hand for it to grow and succeed. When an organization implements inventory models, it will gain a lot in regards to increased profits, low cost on holding inventory, meeting customer demand. When there is effective inventory management in the organization, it helps in loss of sales.

The results of this study led to the conclusion that inventory panning, inventory recording and on shelf arrangement of stock, and inventory control significantly have a positive effect on Pharmaceutical shops' performance. When EOQ is implemented, inventory stocks will be replenished at the right time and correct quantities. For JIT to be a success to the organization the staff should be operating in an active team. JIT minimizes inventory to only what is needed in production. Stock is made only when it is needed.

\section{Recommendations}

Based on the findings of the study, it is essential to give recommendations in order to gather more gains from inventory. It is recommended that;

I. Management should not only undertake Inventory planning in order to improve operation and sustain failing businesses but also improve their competitiveness and financial performance by budgeting for their inventory on weekly basis.

II. To minimize inventory cost through employing proper inventory management practices, it is imperative for the Pharmaceutical shops to know the various cost associated with inventory management for improved performance. This study recommended that the knowledge of these Pharmaceutical shops be enhanced by educating them on the various 


\section{International Journal of Social Science and Economic Research}

ISSN: $2455-8834$

Volume:06, Issue:01 "January 2021"

cost associated with inventory management. This can be done by organizing workshops, seminars and talk shows. This will help the various Pharmaceutical shops to know the various cost to guard against. Some of the relevant cost to keep close watch on includes; Carrying costs (Cost for holding the inventory over time, cost of money tied up in inventory, obsolescence, insurance, personal property taxes, and storage costs), Procurement costs (Cost of preparing the order, Cost of ordering transmissions, Cost of materials handling or processing at the receiving dock, Price of the goods), Out-of-stock costs (Lost sales cost, Profit immediately foregone). If all these costs are properly managed performance will increase.

III. Management should put into consideration the degree of control and evaluation of inventory invested in so that these assets can provide liquidity to the firm with ease. The study found out that control of inventory is mostly done manually which could time consuming. Thus, this study recommends that, inventory control systems should be computerized in order to facilitate control of inventory and most likely eliminate any possible error that could result from manual inventory control. All of these build up to proper inventory management in order to enhance profitability.

\section{BIBILOGRAPHY}

Anichebe, N.A and Agu, O.A (2013) Effect Of Inventory Management On Organizational Effectiveness, Information and Knowledge Management. (3)8.92-100

Abdikani SA, Mahad MA, Mohamed HD (2018) The Role of Inventory Management on Financial Performance in some Selected Manufacturing Companies in Mogadishu. International Journal of Accounting Research 6: 179, doi: 10.4172/2472-114X.100017

Armstrong, J. S. (Ed.). (2001). Principles of forecasting: a handbook for researchers and practitioners (Vol. 30). Springer Science \& Business Media.

Baron, O, Berman, O, \& Perry, D (2010), Shelf Space Management When Demand Depends on the Inventory level, Productions and Operations management, (5),20, 1-14.

Benedict, C., and Margeridis, H. (1999) Chain Reaction Charter, 70(2):464-479

Bin Syed, S. J. A. N., Mohamad, N. N. S., Rahman, N. A. A., \& Suhaimi, R. D. S. R. (2016). A Study on Relationship between Inventory Management and Company Performance: A Case Study of Textile Chain Store. Journal of Advanced Management Science, (4), 4.

Bruin, C. J. D. (1990). Determination, Comparison and Evaluation of Alternative Retail Pharmacy Dispensing Price Structures. Masters Dissertation. University of Pretoria 


\section{International Journal of Social Science and Economic Research}

ISSN: $2455-8834$

Volume:06, Issue:01 "January 2021"

Cacioppo, K.. (2000), “Measuring and Management Customer Satisfaction. Quality Digest

Retrieved on 21st August 2016 from http://qualitydigest.com

David Jessop\& Alex Morrison (1994). Storage and supply of materials,5th edition

Deloof, M. (2003). Does working capital management affect profitability of Belgian firms? Journal of business finance \& Accounting, (30),3-4, 573-588.

Eghan, K., and G. Daniel. (2011), Rapid Assessment of the NTD Pharmaceutical Management System in Cameroon. Submitted to the US Agency for International Development by the Strengthening Pharmaceutical Systems (SPS) Program. Arlington, VA:Management Sciences for Health.

Eneje, B. C., Nweze, A. \&Udeh, A. I. (2012). Effect of Efficient Inventory Managementon Profitability: Evidence From of Selected Brewery Firms in Nigeria.International Journal of Current Research,(4), 11, 350-354

Gary j. Zenz (1997); Purchasing and the management of materials Florida state university, $7^{\text {th }}$ edition, simultaneously, Canada, USA Giese, J. L, and Cote, J.A. (2000), "Defining Consumer satisfaction". Academy of Marketing Science Revenue online 0001.

Harrison, J., Scahill, S., \& Sheridan, J. (2012). New Zealand pharmacists' alignment with their professional body's vision for the future.Research in Social and Administative Pharmacy, (8), 17,35.

Indira, Aroon and Hareen Prakash, (2018) "Romancing Inventory Management"

Joshua Abor, Charles K.D. Adjasi, (2007), Corporate governance and the small and medium size sector: the theory and implications. The international journal of business in society, (7),2, 111-122,

James Ndirangukang'u (2016), IOSR Journal of Economics and Finance (7), 6’ Pp 09-15.

Kesseven, P. (2006). Trends in working capital management and its impact on firm's performance: An analysis of Mauritius small manufacturing firms. International Review of business research papers, (2),2, 45-58

Kilonzo JM, Memba FS, Njeru D (2016) Effect of Inventory Management on Financial Performance of Firms Funded by Government Venture Capital in Kenya. Europe Journal of Business Management 8: 35-41

Kootanaee, A. J., Nagendra, B. \&Hamidreza, F. T. (2013). Just-in-Time Manufacturing System: From Introduction to Implement. International Journal of Economics, 


\section{International Journal of Social Science and Economic Research}

ISSN: $2455-8834$

Volume:06, Issue:01 "January 2021"

Business and Finance,(1),2, $07-25$

Kwame, K. (2007). Working Capital Management Practices of Small Firms in the Asharti Region of Ghana. Retrieved September 15, 2015 from http://www.ssrn.com

Kwadwo, B. P (2016) The Impact of Efficient Inventory Management on Profitability: Evidence fromSeveral Manufacturing Firms in Ghana Industrial, Journal of Finance andAccounting (5), 1,22-2.

Lau A., \& Snell R. (2006); Structure and growth in small Hong Kong enterprises. International Journal of Entrepreneurial Behavior \& Research, (2),3, 29-47

Lwiki, T., Ojera, P. B., Mugend, N., \& Wachira, V. (2013). The impact of inventory management practices on financial performance of sugar manufacturing firms in Kenya. International Journal of Business, Humanities and Technology, (3),5, 75-85

Lydia M. (2016). The effect of Inventory Management on the Firm's Profitability and Operating Cashflows of Kenya Breweries Limited, Beer Distribution Firms in Nairobi County

Mathuva, D. (2010). The Influence of Working Capital Management Components on Corporate Profitability: A Survey on Kenyan listed firms. Research Journal of Business Management, (3), 1,11.

Mercado, E. C. (2007). Hands-on inventory management. London: Auerbach Publications, Taylor \& Francis Group

Mohamud Abukar H (2016). Effects of Inventory Management On Business Performance Of Electronic Companies In Mogadishu. Journal of Business Management, (2),9, 11

Morgamm, N.E.A, and Rego, M. (2005), "Understanding firms Customer Satisfaction Information Usage". Journal of Marketing (69), 131-151

Mugenda, O. M., \& Mugenda, A. G. (2003). Qualitative and quantitative approaches. Research Methods Africa Center for Technology Studies (Acts) Press. Nairobi Kenya.

Muya, T. W. \&Gathogo, G. (2016). Effect of Working Capital Management on the Profitability of Manufacturing Firms in Nakuru Town, Kenya. International Journal of Economics, Commerce and Management, (4),4. 1082 - 1105

Niresh, J. A. \&Velnampy, T. (2014). Firm Size and Profitability: A Study of Listed Manufacturing Firms in Sri Lanka. International Journal of Business and Management, 9(4), 57 - 64 


\section{International Journal of Social Science and Economic Research}

ISSN: $2455-8834$

Volume:06, Issue:01 "January 2021"

Nkiemboupoh, Roland, Abonwi (2017). Inventory management practices and cost. International Journal of Management Studies and Research, (5),7, 24-32, http://dx.doi.org/10.20431/2349.0507005

Vohra N.D (2008), Quantitative Techniques in Management New Delhi, Tata Mc Graw- Hill Publishing Co. Ltd.

Nwangang, P.wGuyo, W and Arasa R. (2015) Influence of Inventory Management on Performance of Manufacturing Firms in Keya "International Journal of Logistics and Management (2), 1, 23-44

Nyabwanga, R. N., Ojera, P., Lumumba, P., Odondo, A. J. \&Otieno, S. (2012). Effects of Working Capital Management Practices on Financial Performance: A Study of Small Scale Enterprises in Kisii South District, Kenya. Africa Journal of Management, (6), 18, 5807 - 5817.

Obiri-Yeboah, H., Ackah, D. \&Makafui, R. A. (2015). Assessing the Impact of Efficient Inventory Management in on Organization. International Journal of Advanced Research in Computer Science and Software Engineering,(5),8, 86-103

Ogbo, A. I.,Onekanma I. V and Wilfred I. U (2014)The Impact of Effective Inventory Control Management on Organizational Performance: A Study of 7up Bottling Company Nile

Mile Enugu, Nigeria, Mediterranean Journal of Social Sciences,(5), 10

Panigrahi, A. K. (2013). Relationship between Inventory Management and Profitability: An Empirical Analysis of Indian Cement Companies. Asia Pacific Journal of Marketing \& Management Review. (2),7, pp107-120

Kotler P. (2002), Marketing Management, (2002). The Millennium Edition, (2nd ed). New Delhi: Prentice Hill of India, 2002

Pandey, I. M. (2008). "Financial Management", 10th Edition. New Delhi: Vikas Publishing House Private Limited

Patel, G. N., \&Pande, S. (2012). Measuring the performance of pharmacy stores using discretionary and non-discretionary variables.OPSEARCH. doi:10.1007/s12597-0120095-0

Prempeh, K. B. (2016). The impact of efficient inventory management on profitability: evidence from selected manufacturing firms in Ghana. International Journal of Finance and Accounting, (5), 1, 22-26. 


\section{International Journal of Social Science and Economic Research}

ISSN: $2455-8834$

Volume:06, Issue:01 "January 2021"

Rafuse, M. E. (1996). Working capital management: an urgent need to refocus. Management Decision,(34), 2, 59-63.

Raheman, A., \& Nasr, M. (2007). Working capital management and profitability-case of Pakistani firms. International review of business research papers, (3), 1, 279-300.

Shardeo.V. (2015), Impact of inventory management on the financial performance of the firm, IOSR Journal of Business and Management, (17), 4, Pp 1-12

Shin, S., Ennis, K. L. \&Spurlin, W. P. (2015). Effect of Inventory ManagementEfficiency on Profitability: Current Evidence from the U.S. ManufacturingIndustry. Journal of Economics and Economic Education Research,(16),1, 1-15

Schmidt, R. A., \&Pioch, E. A. (2001). Ten years after: the impact of German unification on retail Pharmaceutical shops. International Journal ofRetail and Distribution Management, (29),5, $247-258$

Smaros S.J., Lehtonen, J.M. Appelquist, P. and Holmstrom, J. (2003) The Impact of Increasing Demand Visibility on Production and Inventory Control Efficiency, International Journal of Physical Distribution and Logistics, (33),4, 445-465.

Temeng, V. A., Eshun, P. A., \&Essey, P. R. K. (2010). Application of inventory management principles to explosive products manufacturing and supply-a case study. International research journal of finance and economics, 38, 198-209

Truch, E (2006), "Lean Consumption and its Influence on brand" Journal of Con Widding, (2003), The 3Ts of Highly Effective Chains. Journal of Supply Chain Practice (5) .3

Vohra PS, Dhillon JS (2014) Best Financial Practices Lead Financial Performance of SMES. International Journal Account, Finance and Management Research (IJAFMR), 4:5-16

WIlliams, K. F. (2007). Re-examining 'professionalism' in pharmacy: A South African perspective. 